\title{
Chinese Language Teaching Professional Ability Training
}

\author{
Tang Jianghua \\ Yunnan College Foreign Languages and Foreign Affairs Yanglin 651700 \\ 85463999@qq.com
}

Keywords: Higher Vocational Chinese; Professional Ability; Teaching

\begin{abstract}
Higher vocational Chinese teaching is an important course of higher vocational education, which has played an active role in transforming vocational students' vocational ability. However, with the development of higher vocational education, a single teaching content cannot meet the needs of vocational education. From the perspective of professional ability, this party explores the positive role of vocational Chinese in professional competence and the strategy of teaching reform to promote the unity of Chinese language teaching and the development of students' professional competence.

In order to promote the development of modern vocational education, the State has promulgated the "Decision of the State Council on Energetically Developing Vocational Education." The decision states: "Vocational education must improve the quality of workers, especially professional capabilities," and "provide students with professional ethics and professional abilities." The employment rate serves as an important indicator for assessing the education and teaching work in vocational colleges." The "Opinions of the Ministry of Education on Improving the Teaching Quality of Higher Vocational Education in an All-round Way" pointed out: "Higher vocational education is a type of higher education development ... and it strengthens the cultivation of students' professional abilities." It is not difficult to see that the task of higher vocational education is to cultivate technically applied talents with good ideological and moral qualities and strong professional abilities to meet the demand for talents in economic and social development. Vocational Chinese teaching combines the instrumentality, practicality, humanity, and aesthetics of Chinese language teaching with the goal of cultivating students' professional qualities and vocational skills. This is a public basic course for higher vocational education, which is in the Ministry of Education. The university language-teaching syllabus issued also clearly stipulates. However, at present, due to the influence of pragmatism and meristems, Chinese teaching in higher vocational colleges is far from adapting to the requirements of social development on students' professional ability. To a certain extent, it condemns the realization of the goals of higher vocational education and the formation of characteristic education. . Therefore, in vocational Chinese teaching, according to the goal of personnel training in vocational education, starting from the characteristics of the Chinese discipline itself, we should pay attention to the cultivation of students' professional ability.
\end{abstract}

\section{The Connotation of Professional Ability}

Occupational ability is a synthesis of the many abilities that a person has in a particular profession. Based on different cultural backgrounds and research perspectives, people have different understanding and definition of professional competence. For example, some schools divide professional ability into general vocational ability, professional ability, and comprehensive ability. Some scholars divide professional ability into basic professional ability and key professional ability, while basic professional ability is divided into professional ability, method ability, and society ability. This shows that professional ability is our necessary ability to perform a career, which will affect our development in this profession. 


\section{The Role of Cultivating Students' Professional Ability in Chinese Teaching}

\section{Improve students' speaking and writing skills}

Chinese language teaching in higher vocational colleges also cultivates students' ability to speak, speak, read and write. This ability must be professional and use and operability. For example, in the tourism management major and the guide course teaching, students' oral and written training can be strengthened through the teaching of higher vocational Chinese. In the study of ancient poetry units, in addition to the poetry meal in the teaching materials, the ancient poetry and recitation of landscape poems can be appropriately increased. The students can perform oral expression training with each other during classes, such as memorizing poems and news broadcasts; At the same time, there are tour guides in the tour guides' professional courses. In the writing of Chinese teaching, we can use professional knowledge guides to explain (attractions) without subject and train. Not only writing, but also expressions for recitation. Strengthen the professional application ability of students.

\section{Training students' professional ethics and professionalism}

In the process of Chinese teaching in higher vocational schools, the integration of professional moral education must make full use of the ideology of textbooks, the vividness of literary works, and the instrumentality of literary language, consciously guide and train students, and help students establish correct professional ethics. Professionalism. For example: Teachers' professions "preaching, teaching, dispelling doubts". Accounting professional ethics: honesty and trustworthiness, love and dedication, etc., Nursing majors: saving lives and so on. For example, for nursing students, at the beginning of the school year, students are allowed to read Dr. Wang Sunsi's "Big Medical Experts" article. "Great Medical Doctors" discusses two issues related to doctors. The first is the essence, and the other is the requirement that the healers have superb medical skills. He believes that the doctor's morality is "to the finest things," and those who practice medicine must "Bo doctor medical source, hard and tireless." The second is sincerity, that is to say, the healers are required to have a noble moral character cultivation, and to "see the other person's distress, if they have it" with the same heart. In language learning, students should be made aware of the concept of medical ethics that should be used by doctors. This will perfectly combine professional professionalism with language teaching.

\section{Improve students' communication and collaboration skills}

We are all social people living in the world. Everyone faces the problem of interpersonal communication. Even Robinson Crusoe, who lived on an isolated island, had to deal with the servant "Friday." In all careers, there are few jobs that deal with people. Therefore, good communication and collaboration skills are important for every career. In the language teaching process, we can adopt appropriate ways to cultivate students' abilities, shift the teaching objectives of the curriculum to students' professional skills, and focus on cultivating students' professional communication and collaboration skills. For example, student characters in Chinese language teaching, as well as scene performances.

\section{Cultivate students' creative thinking}

A public basic course in vocational Chinese language not only examines students' abilities of listening, speaking, reading and writing but also pays attention to creative thinking and innovative consciousness in the cultivation of professional ability. Although Chinese language teaching in higher vocational colleges attaches great importance to the innovation of literature, it also attaches great importance to stimulating students' creative thinking. Mr. Guo Moruo points out profoundly: "Science also needs to be created. It needs illusions and illusions to break the traditional bondage and develop science." Therefore, we also need to leave blank areas for students in the teaching process so that students can give full play to their own creative thinking, to create potential, so that potential and professional ability combined together to form a good teaching effect. For example: In the teaching process of art design, our school allows students to use the basis of art to draw the characters they understand in their hearts. Many students have drawn different characters through their own understanding. They are abstract, vivid, youthful, and old. This combines the perfect combination of language and art. Painting skills are also one of the professional skills of art design 
students.

\section{Higher Vocational Chinese Teaching Measures Based on Professional Ability Training}

\section{Change the teaching philosophy}

The 21 st century is a rapidly evolving era of knowledge economy. The new era has given the education a new mission and requirements. The training objective of vocational education is to cultivate practical and applied talents. Chinese teaching is not just a "reading machine" that is rote memorized. We must target vocational students' vocational ability services in higher vocational Chinese, such as the training of professional nursing students and tourism management students in language teaching and professional competence. We no longer think of higher vocational Chinese as an open and inalienable choice but also a choice, and the students we cultivate in vocational colleges must be students with more comprehensive abilities. In this way, it is conducive to the development of teaching in higher vocational Chinese language, which also conforms to the nature and laws of educational development.

\section{Strengthen students' learning ability}

The famous educator, Mr. Ye Shengtao, said: "College graduates may not write novels or poetry, but they must write practical and practical articles in their work and life, and they should not be fluent and solid." Among them, "practical articles" are applied texts. . This is precisely the teaching goal of higher vocational Chinese and is used for professional purposes.

The reason why vocational Chinese education has not been substantially improved is, in the final analysis, because students' enthusiasm and initiative have not been improved. At the same time, due to the students' source characteristics of higher vocational colleges, this requires our teachers to change their methods in the teaching process. Students establish a correct learning concept, and truly implement the theory and practice of vocational education. As a result, students' professional knowledge and professional ability are improved. At the same time, humanistic qualities have also been well developed and the overall quality of students has been improved.

\section{Improve teaching forms and evaluation methods}

The teaching content of higher vocational Chinese language should be integrated with the times, highlight the characteristics of the times, focus on real life teaching experience, strengthen the connection between the classroom and reality, expand the teaching resources as much as possible, and integrate the textbooks with modern teaching methods. For example: Micro lessons, admiring lessons, flipping classes, etc. Even if the materials are fully utilized, they can stimulate students' interest in learning.

The evaluation of higher vocational Chinese education is a summary of the expected accomplishment in the teaching process of higher vocational Chinese education, the realization of examination goals, and the degree of educational efficiency. It is an indispensable part of the innovation of Chinese teaching in higher vocational education. Take our school as an example. Our appraisal of teachers is only the final evaluation of education, and more consideration is given to the teacher's usual teaching effectiveness evaluation, teaching standards, scientific research participation, and student feedback in class. And for the exam is not a final exam paper, the school now uses a computer test, a comprehensive reply and so on. The evaluation method has undergone great changes. Students no longer learn Chinese for the sake of the exam, they are no longer afraid of the language exams, and they are full of information each time they are tested. At the same time, teachers also reduce some of the end-of-term review workload.

\section{Improve the quality of teachers}

Many language teachers in higher vocational colleges are generally low in academic qualifications, professional titles, and ages. They may either go to public institutions or go to some primary and secondary schools to create a shortage of teachers in higher vocational colleges. The career development of teachers needs a long process. However, we need the "dual-qualified" teachers with the best theory and skills. In this way, according to the characteristics of different professions, according to the characteristics of different professions, we can adopt the teaching strategies of "multi-teaching" and "combination of text and teaching" to achieve the integration of 
language and professional skills. Therefore, schools should adopt certain incentive policies to encourage teachers, upgrade their academic qualifications, evaluate job titles, and train their employees in order to allow them to have room for improvement.

The goal of talent training in higher vocational Chinese teaching is to improve students' professional ability. In the teaching of higher vocational Chinese language, we should focus on professional ability, update concepts, take professional demands as the direction, pay attention to the cultivation of students' practical ability, innovative thinking and social skills, and close professional knowledge and job skills. The combination will combine the student's career development and social development trends, continuously improve the students' overall quality, improve their professional ability, and provide talents for economic and social development.

\section{References}

[1] Pan Shufen, Reflections on the Current Situation and Improvement Measures of Chinese Teaching in Higher Vocational Colleges [J], April 2017

[2]Liu Wei, The Reform of Vocational Chinese Teaching Model with Professional Ability as the Goal, Education modernization [J], 2017.16.025

[3] Li Lugen, Yang Xibin, Analysis of Vocational Chinese Teaching Reform Based on Professional Ability, Language and Literature Studies [J], November 2009 issue

[4] Li Zhaohui, Chinese Teaching Reform in Higher Vocational Colleges Based on Professional Ability Cultivation, Journal of Changchun Normal University [J], September 2016

[5] Su Xiaohong, On Cultivation of Students' Professional Ability in Higher Vocational Chinese Teaching, Vocational education research [J], 2009.10

1 Tang jianghua(1981.11 --) Master's degree, lecturer, backbone teacher, Yunnan Foreign Language Vocational College, Tel: $1388824476785463999 @ q q . c o m$ 